\title{
1-METHYLCYCLOPROPENE AND AMINOETHOXYVINYLGLYCINE EFFECTS ON YIELD COMPONENTS OF FIELD-GROWN COTTON
}

\author{
Efeitos de 1-Methylcyclopropeno e Aminoethoxyvinylglycina sobre \\ componentes de rendimento de algodoeiros crescidos sob condições de campo
}

\author{
Giovani Greigh de Brito ${ }^{1}$,Alexandre Cunha de Barcellos Ferreira², Ana Luiza Dias CoelhoBorin², CamilodeLelis Morello²
}

\begin{abstract}
Biotic and abiotic stresses can alter the hormone balance and trigger the activation of pathways involved in the cotton stress responses, resulting in the abscission of squares, flowers and young bolls and consequent reductions in the seed cotton yield and fiber yield. As part of the mechanism that primarily regulates the protective response of plants against stresses, ethylene is considered a key hormone involved in this response, and increased ethylene synthesis has been observed when plants are subjected to stress. Thus, the development of strategies aimed to mitigate their negative effects can reduce the shed rate of reproductive structures and positively impact cotton productivity. For this purpose, 1-methylcyclopropene (1-MCP), a compound that inhibits the action of ethylene, and aminoethoxyvinylglycine (AVG), an ethylene synthesis inhibitor, were sprayed on cotton plants to investigate their effects on the seed cotton yield (SCY), fiber yield (FY), fiber percentage (\% Fiber) and final stand of plants (STAND) during two cotton growth seasons (2010 and 2011). To this end, experiments were performed in a randomized complete block design with five replicates. Our results demonstrate that the inhibitors of ethylene synthesis and action increased the seed cotton and fiber yield during both growing seasons. The results obtained after AVG spraying in the initial reproductive phase (first square emission) presented the highest values for the cotton yield components and are the first record of the success of this method in Brazil.
\end{abstract}

Index terms: AVG, 1-MCP, ethylene, Gossypium hirsutum.

\section{RESUMO}

A ocorrência de estresses bióticos e abióticos pode alterar o balanço hormonal e desencadear a ativação de vias envolvidas nas respostas do algodoeiro a estresses, resultando na abscisão de botões, flores e maçãs em desenvolvimento e em menor rendimento de algodão em caroço e de fibras. Como parte desses mecanismos que primariamente regulam as respostas protetivas da planta contra estresses, o etileno é considerado um hormônio chave, envolvido nessas respostas e aumentos em seu nível de síntese têm sido verificados em plantas submetidas a quaisquer tipos de estresse. Assim, o desenvolvimento de estratégias objetivando mitigar os seus efeitos negativos poderia reduzir a taxa de queda de estruturas reprodutivas e impactar positivamente na produtividade de fibras. Com esse propósito, 1-methylcyclopropeno (1-MCP), um composto inibidor da ação do etileno e aminoethoxyvinylglycina (AVG), um inibidor da sua síntese foram aplicados sobre o algodoeiro para investigar seus efeitos sobre o rendimento de algodão em caroço, de fibras, a percentagem de fibras e o stand final de plantas durante duas estações de crescimento (2010 e 2011). Assim, experimentos a campo em delineamento blocos casualizados completo com cinco repetições foram conduzidos. Os resultados obtidos evidenciam que os inibidores da síntese e da ação de etileno aumentaram o rendimento de algodão em caroço e de fibras em ambas as estações de crescimento. Os resultados obtidos pelo uso do AVG aplicado na fase reprodutiva inicial (primeiro botão floral) evidenciaram os maiores valores para os componentes de rendimento analisados, sendo os primeiros resultados obtidos no Brasil com tal propósito.

Termos para indexação: AVG, 1-MCP, etileno, Gossypium hirsutum.

(Received in august 21, 2012 and approved in december 12, 2012)

\section{INTRODUCTION}

Abiotic and biotic stresses represent the major constraints that result in agricultural losses on the global scale, and projected climate changes could increase their negative effects in the future (INTERGOVERNMETAL PANELON CLIMATE CHANGE-IPCC, 2007; FISCHER; SCHAR, 2010).

Cotton (Gossypium hirsutum L. r. latifolium) is the major fiber crop; however, cotton yields are often limited due to the extreme sensitivity of this crop to environmental stressors, such as high temperature and drought. Cotton plants are continuously exposed to various biotic and abiotic stresses during growth in their natural environment. Under such conditions, cotton plants can evoke intricate mechanisms to perceive external signals, allowing the optimal response to the environmental conditions. As components of these mechanisms, plant hormones, including abscisic acid (ABA), jasmonic acid (JA), salicylic

\footnotetext{
${ }^{1}$ Empresa Brasileira de Pesquisa Agropecuária/Embrapa - Algodão - Centro Nacional de Pesquisa de Algodão/CNPA - Núcleo do Cerrado - Cx.P. 179 - 75375-000 - Santo Antônio de Goiás - GO - Brasil - giovani.brito@embrapa.br

²Empresa Brasileira de Pesquisa Agropecuária/Embrapa - Algodão - Centro Nacional de Pesquisa de Algodão/CNPA-Núcleo do Cerrado - Santo Antônio de Goiás - GO - Brasil
} 
acid (SA) and ethylene (ET), are endogenous, low molecular weight molecules that primarily regulate the protective responses of plants against both biotic and abiotic stresses via synergistic and antagonistic actions, which are referred to as signaling crosstalk (FUJITA et al., 2006). Among these molecules, ethylene is considered to be the stress hormone, and increased ethylene levels have been verified when plants are subjected to abiotic and biotic stresses (TAIZ; ZEIGER, 2010). Thus, under field conditions, cotton plants are often exposed to environmental stresses, such as unfavorable temperatures, solar radiation and water availability, particularly during critical stages and during the initial reproductive phase and boll development. During these phases, stress alters the hormone balance and triggers the activation of pathways involved in the stress response, resulting in the abscission of squares and young bolls and the abortion of flowers, causing a reduced seed cotton yield and, consequently, lower fiber yield (STEWART, 2010; BRITO et al., 2011). Additionally, an increase in reproductive structure shedding occurs through an increase in ethylene production (STEWART et al., 2010). In this context, in the Brazilian Savannah biome where approximately $90 \%$ (1.2 million Hectares) of the cotton crop is grown, drought events historically occur from April to May, particularly in the state of Goiás, the third largest cotton producer in Brazil. In this region, the reduction in rainfall historically begins in April (INSTITUTO NACIONAL DE METEOROLOGIA-INMET, 2012), coinciding with the first cotton flowering emission and early cotton boll development phase, during which the plants' demand for water is significantly increased (STEWART et al., 2010), especially for the second crop growth season, or "safrinha", as farmers in Brazil call it. In the last three growth seasons (2009-10, 2010-11 and 201112), the fiber yield was reduced by approximately $30 \%$ due to the occurrence of drought events during the reproductive phase during the second crop season (personal communication). Additionally, cloudy weather is common during the cotton growing season, especially in December and January (INMET, 2012), increasing the ratio of shed reproductive structures, including squares, flowers and bolls, in the initial development phase (preferentially bolls with diameters less than $2 \mathrm{~cm}$ ) (Personal communication). Therefore, the development of strategies aiming mitigate the negative effects of common stressors during the cotton growth season could reduce the shed rate and, consequently, increase cotton productivity and sustainability in the Brazilian Savannah region.

For this purpose, plants were sprayed with 1-MCP, a compound that inhibits the action of ethylene by occupying the receptor site, and AVG, which inhibits synthesis by binding to aminociclopropane-1- carboxylic (ACC) synthase enzyme and blocking the conversion of S-adenosylmethionine to 1-aminoclopropane-1-caboxilic acid (ACC), the immediate precursor in the ethylene biosynthesis pathway.

In this context, we hypothesized that spraying cotton plants with 1-MCP and AVG would inhibit the action or synthesis of ethylene and could thus mitigate plant stressors, which are common during all growth seasons, particularly in the reproductive phase, to mitigate yield loss. Our objective was to then investigate the effects of the ethylene compounds (1-MCP and AVG) on cotton yield components under field conditions on alleviating the adverse effects of the environmental stress experienced during the season on square and boll development and thereby on reducing the yield variability and allowing higher productivity.

\section{MATERIALS AND METHODS}

To investigate whether these compounds (1-MCP and AVG) could mitigate the negative effects of ethylene on cotton yield components, experiments were conducted in two growth season (2010 and 2011) in Santa Helena de Goias, GO (17 48' 49' ' S, 50' 35' 49' 'W, at $563 \mathrm{~m}$ altitude). The cotton (Gossypium hirsutum L.) cultivar BRS 293 was sowed on December 18, 2010, for the first growing season and on February 09, 2011, for the second growing season, or "safrinha". Before cotton was sowed Sorghum bicolor (L.) Moench and Glycine $\max (\mathrm{L}$.) Merr.

For these two experiments, the first square was emitted at 37 (on January 24, 2011) and 32 (on March 13, 2011) days after sowing during the first and second growth seasons, respectively. Between the first square emission and the physiological cutout (cessation of new vegetative and reproductive growth) $589.7 \mathrm{~mm}$ and $287.5 \mathrm{~mm}$ of rainfall were accumulated for first and second growing season, respectively. Additionally, climatic data were registered during the growth cycle, and the historic rainfall and temperature data are presented (Table 1).

For this purpose, the BRS 293 cultivar was sowed in a randomized complete block design with five replicates for both experiments. The plot size was 4 rows by $5 \mathrm{~m}$, with a row spacing of $0.80 \mathrm{~m}$ and a plant density of 9 plants $\mathrm{m}^{-1}$. For the second growth season, the cotton seeds were sowed using a row spacing of $0.45 \mathrm{~m}$ and a density of 8 plants $\mathrm{m}^{-1}$. For the first growth season, starter fertilizer (04-30-16 of $\mathrm{N}-\mathrm{P}-\mathrm{K}$, respectively, plus $0.4 \%$ Boron and Zinc) at a 
rate of $400 \mathrm{~kg} \mathrm{ha}^{-1}$ was band-applied adjacent to each row at planting. The cotton was side dressed with two applications; the first dose of $250 \mathrm{~kg} \mathrm{ha}^{-1}$ of 2000-30 plus $0.3 \%$ boron was applied at square initiation and the second dose of $250 \mathrm{~kg} \mathrm{ha}^{-1}$ of ammonium sulfate at first flower emission. For the second growth season, starter fertilizer (04-30-16 of N-P-K, respectively, plus $0.4 \%$ Boron and Zinc) at a rate of $300 \mathrm{~kg} \mathrm{ha}^{-1}$ was band-applied adjacent to each row at planting. The cotton was side-dressed with 20-00-00 of N-P-K, respectively, plus $0.3 \%$ boron at application using $250 \mathrm{~kg} \mathrm{ha}^{-1}$ at square initiation. Plant growth regulation and weed, disease and insect control management was performed according to the cotton crop recommendations for the Brazilian Savannah (TAKIZAWA, 2011).

The treatments consisted of $\left(\mathrm{T}_{1}\right)$, an untreated control, where only water was applied, $\left(\mathrm{T}_{2}\right) 1-\mathrm{MCP}$ at $10 \mathrm{~g}$ ai ha ${ }^{-1}$ was applied at first square emission with a second dose seven days after the first application, $\left(\mathrm{T}_{3}\right) 1-\mathrm{MCP}$ at $10 \mathrm{~g}$ ai ha ${ }^{-1}$ was applied at first square emission along with two applications with intervals of seven days between each entry, $\left(\mathrm{T}_{4}\right) 1-\mathrm{MCP}$ at $10 \mathrm{~g}$ ai ha-1 was sprayed at first flower emission with another two applications with intervals of seven days between each entry, $\left(\mathrm{T}_{5}\right)$ AVG at $30 \mathrm{~g}$ ai ha $^{-1}$ was applied at first square emission with a second application seven days after the first application and $\left(\mathrm{T}_{6}\right)$ AVG at $30 \mathrm{~g}_{\text {ai ha }}{ }^{-1}$ was applied at first flower emission with a second application seven days after the first application. The dose defined for 1-MCP was based on the results obtained by Kawakami and co-authors (KAWAKAMI; OOSTERHUIS; SNIDER, 2010), while the AVG dose was defined based on the results obtained in a first trial (unpublished data).

For two growth seasons, the seed cotton yield (SCY), fiber yield (FY), fiber percentage ( $\%$ Fiber) and final plant stand (Stand) at maturity were measured. For this purpose, the yield components were measured from the two central rows of each plot (plants were picked from 10 meters of each plot). For the SCY, the picked bolls were placed into kraft paper bags, and the total product was cleaned and weighed using an electrical balance. The data were calculated and expressed in $\mathrm{kg}$ per ha. For the fiber yield, clean and dry samples of seed cotton from each plot were weighed and ginned with a single roller electric gin. The lint percentage was calculated by dividing the lint weight by the total weight of seed cotton in the sample. This characteristic was recorded as the percentage. The final stand was calculated based on the average plant number in 10 linear meters, considering the two central rows of each plot.

The homogeneity of variances was tested by the Bartlett test, and the data were subsequently subjected to analysis of variance (ANOVA). The Least Significant Difference (LSD) among the means was statistically analyzed using Student's t-test $(\mathrm{p}<0.05)$. Contrast analyses using the average of the principal effects of the doses were performed to compare the two ethylene compounds, the application phase and the untreated plot $(\mathrm{p}<0.05)$.

\section{RESULTS AND DISCUSSION}

Considering that there was an interaction effect between the experiments and the treatments, the data were

Table 1 - Monthly mean maximum and minimum temperatures and accumulated rainfall during the cotton growth season experimental periods. Historical climatic data are shown for this location.

\begin{tabular}{lcrrrcr}
\hline \multirow{2}{*}{ Period } & \multicolumn{3}{c}{ Santa Helena de Goiás - GO } \\
\cline { 2 - 7 } & \multicolumn{2}{c}{$\operatorname{Tmax}^{\circ} \mathrm{C}$} & \multicolumn{2}{c}{$\operatorname{Tmin}^{\circ} \mathrm{C}$} & \multicolumn{2}{c}{ Rainfall (mm) } \\
\hline December & 29.21 & $29.50 \dagger$ & 19.27 & $19.50 \dagger$ & 147 & $185 \dagger$ \\
January & 28.44 & 29.10 & 19.65 & 19.50 & 256 & 264 \\
February & 30.31 & 30.10 & 20.07 & 19.40 & 187 & 208 \\
March & 32.00 & 30.10 & 20.92 & 19.40 & 185 & 213 \\
April & 30.54 & 29.20 & 17.47 & 17.90 & 51 & 71 \\
May & 29.46 & 28.40 & 13.99 & 16.40 & 00 & 28 \\
June & 29.78 & 27.80 & 11.57 & 14.70 & 05 & 13 \\
July & 30.88 & 28.00 & 12.54 & 14.10 & 01 & 07 \\
August & 32.08 & 30.70 & 10.98 & 15.70 & 00 & 13 \\
\hline
\end{tabular}

$\dagger$ The average from at least forty years at Santa Helena de Goiás, GO, Brazil (Data from Inmet). 
statistically analyzed for each experiment. In the first growth season, the analysis of the SCY data showed that the following treatments led to significantly higher seed cotton yield values compared to $\left(T_{1}\right)$, where only water was sprayed (control treatment): $\left(\mathrm{T}_{3}\right)$, involving $1-\mathrm{MCP}$ at $10 \mathrm{~g}$ ai ha ${ }^{-1}$ sprayed at the first square emission and two additional applications at seven-day intervals, $\left(\mathrm{T}_{4}\right)$, involving 1-MCP at $10 \mathrm{~g}$ ai ha ${ }^{-1}$ at first flower emission and two more applications at an interval of seven days, $\left(\mathrm{T}_{5}\right)$, involving AVG at $30 \mathrm{~g}$ ai ha $\mathrm{h}^{-1}$ sprayed at the first square emission and a second application seven days later and $\left(\mathrm{T}_{6}\right)$, involving $\mathrm{AVG}$ at $30 \mathrm{~g}$ ai ha ${ }^{-1}$ applied at the first flower emission and a second application seven days after the first (Figure 1A). Although not significant, AVG treatment at the first square emission phase with a second application seven days later $\left(\mathrm{T}_{5}\right)$ produced the largest SCY values compared to those treatments involving 1$\mathrm{MCP}$ and AVG in the other regimens (Figure 1A). These results clearly demonstrate that ethylene inhibition in the initial reproductive phase can act not only reduce the ratio of shed squares and allow the plants to sustain higher productivity but can also define the development phase where ethylene production is critical for high cotton yields.
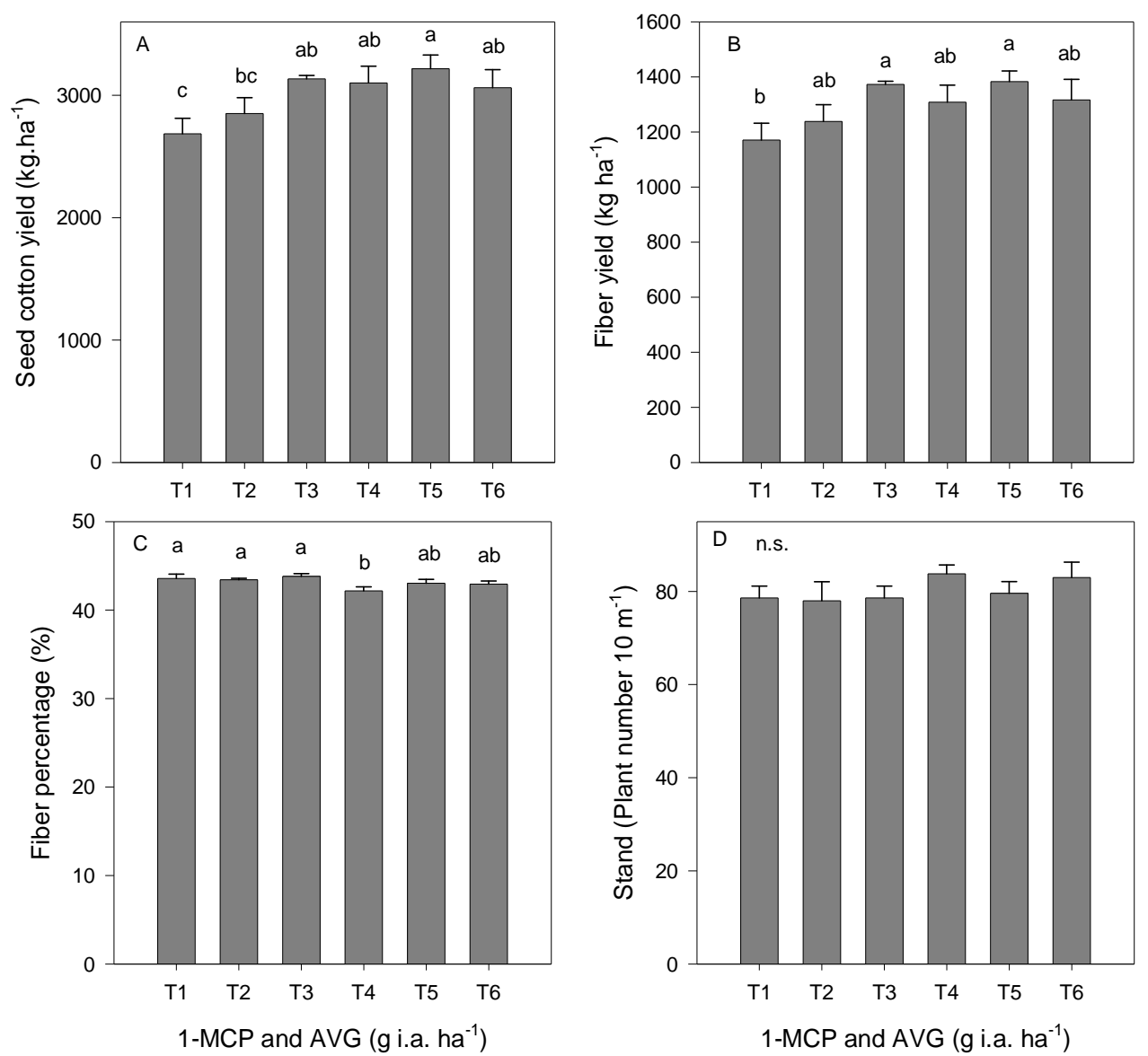

Figure 1 - Cotton yield components from plants subjected to the two sources of ethylene inhibitor compounds during the reproductive phase of the first growing season. $\mathrm{T}_{1}$ refers to the control where only water was applied; $\mathrm{T}_{2}-1-\mathrm{MCP}$ applied at the first square emission with a second application seven days after the initial application; $\mathrm{T}_{3}-1-\mathrm{MCP}$ applied at the first square with two additional applications with intervals of seven days between each application; $\mathrm{T}_{4}-1$-MCP applied at the first flower emission with two additional applications with intervals of seven days between applications; $\mathrm{T}_{5}-\mathrm{AVG}$ applied at the first square emission with a second application seven days after the initial application; and $\mathrm{T}_{6}$ - AVG applied at the first flower emission with a second application seven days after the initial application. Means followed by the same letter are not significantly different at the $\mathrm{p}<0.05$ level by Student's statistical test (LSD). 
In terms of FY, the treatments initiated at the first square emission $\left(\mathrm{T}_{3}\right.$ and $\mathrm{T}_{5}$ ) resulted in the highest performance, independently of the mode of action of the compounds (figure 1B), when compared to the untreated control. The fiber percentage analysis showed that only $\mathrm{T}_{4}$ was significantly lower than the control treatment (Figure $1 \mathrm{C}$ ), while a significant difference was not observed for the final Stand of the plants (Figure 1D). Additionally, only $\hat{\mathrm{Y}} 1$ and $\hat{\mathrm{Y}} 2$, named as 1 and 2 contrasts, respectively, showed significant differences in the SCY and FY in the first growing season (Table 2).

In this report, we have shown that ethylene inhibitors can reduce the negative effects of environmental stress on the SCY and FY variables, which were increased compared to the untreated control. Under these conditions, $589.7 \mathrm{~mm}$ of rainfall accumulated (from the first square emission until the cut out phase), which satisfied the water demands of the cotton at this location, is an indicative that other types of stress were present during this growing season period. In fact, because the optimal temperature for cotton photosynthesis, growth and development is approximately $27^{\circ} \mathrm{C}$ and because boll growth virtually ceases above $33^{\circ} \mathrm{C}$, any factor (e.g., temperature, turgor loss, photosynthate supply, or mechanical damage) that reduces the boll growth rate can cause an increase in ethylene production and reduce the indole - 3 - acetic acid (IAA) supply, which, in turn, causes fruit shedding and delays stem development. As shown in the table 1, the mean maximal temperatures were always above $27^{\circ} \mathrm{C}$ during all growing periods in these experiments, indicating that the cotton plants experienced stress due to high temperatures at some point during the growth seasons. Additionally, the occurrence of cloudy weather is very common during the months of January and February at this location, coinciding with the initial reproductive phase of the experiment conducted during the first growing season. Although commercial cotton genotypes are considered "day neutral" with respect to flowering and fruiting, cloudy weather during the reproductive phase has been shown to have a negative impact on physiological pathways. These impacts involve gas exchange, chlorophyll fluorescence and hormone balance variables, including increased ethylene synthesis, thus increasing the square, flower and boll shedding ratios, particularly during the initial development phase (STEWART et al., 2010).

In the second growing season, during which the water deficit was more severe $(287.5 \mathrm{~mm}$ of rainfall accumulated from square emission until cut out), the yield components, such as SCY and FY, were significantly reduced compared to the first growth season $(589.7 \mathrm{~mm}$ of rainfall accumulated from square emission until cut out). Under these conditions, the 1-MCP applications increased the FY by $135.52 \mathrm{~kg} \mathrm{ha}^{-1}$ compared to the untreated control, independently of the application phase (Table 2). In the AVG treatments, there was an increase of $178.83 \mathrm{~kg} \mathrm{ha}^{-1}$ in the FY compared to the untreated control (Table 2).

Table 2 - Estimate of the orthogonal contrasts relative to the seed cotton yield (SCY) and fiber yield (FY) from cotton sprayed with ethylene inhibitors.

\begin{tabular}{|c|c|c|c|c|c|}
\hline \multicolumn{2}{|c|}{ Contrast at first cotton growth season } & $\mathrm{SCY}_{\text {estimate }}$ & $\operatorname{Pr}>|t|$ & FY $Y_{\text {estimate }}$ & $\operatorname{Pr}>|t|$ \\
\hline$\hat{\mathrm{Y}}_{1}=\mathrm{T} 2, \mathrm{~T} 3$ and $\mathrm{T} 4(1-\mathrm{MCP})$ & vs. T1 (Control - water) & 343.06 & 0.021 & 135.52 & 0.045 \\
\hline$\hat{\mathrm{Y}}_{2}=\mathrm{T} 5$ and $\mathrm{T} 6(\mathrm{AVG})$ & T1 (Control - water) & 454.12 & 0.005 & 178.83 & 0.015 \\
\hline$\hat{\mathrm{Y}} 3=\mathrm{T} 5$ and $\mathrm{T} 6(\mathrm{AVG})$ & $\mathrm{T} 2, \mathrm{~T} 3$ and $\mathrm{T} 4(1-\mathrm{MCP})$ & 85.11 & 0.460 & 54.427 & 0.308 \\
\hline$\hat{\mathrm{Y}} 4=\mathrm{T} 3$ (1-MCP at first square) & T4 (1-MCP at first flower) & 32.00 & 0.852 & 64.70 & 0.418 \\
\hline$\hat{\mathrm{Y}} 5=\mathrm{T} 5$ (AVG at first square) & T6 (AVG at first flower) & 155.65 & 0.369 & 66.69 & 0.404 \\
\hline \multicolumn{2}{|c|}{ Contrast at second cotton growth season } & SCY estimate & $\operatorname{Pr}>|t|$ & $\mathrm{FY}_{\text {estimate }}$ & $\operatorname{Pr}>|t|$ \\
\hline$\hat{\mathrm{Y}}_{1}=\mathrm{T} 2, \mathrm{~T} 3$ and T4 (1-MCP) & T1 (Control - water) & 223.95 & 0.014 & 109.50 & 0.004 \\
\hline$\hat{\mathrm{Y}}_{2}=\mathrm{T} 5$ and $\mathrm{T} 6(\mathrm{AVG})$ & T1 (Control - water) & 388.03 & 0.000 & 161.75 & 0.000 \\
\hline$\hat{\mathrm{Y}} 3=\mathrm{T} 5$ and $\mathrm{T} 6(\mathrm{AVG})$ & T2, T3 and T4 (1-MCP) & 203.96 & 0.007 & 33.86 & 0.237 \\
\hline$\hat{\mathrm{Y}} 4=\mathrm{T} 3$ (1-MCP at first square) & T4 (1-MCP at first flower) & 41.20 & 0.695 & 37.70 & 0.377 \\
\hline$\hat{\mathrm{Y}} 5=\mathrm{T} 5$ (AVG at first square) & T6 (AVG at first flower) & 239.30 & 0.030 & 110.30 & 0.015 \\
\hline
\end{tabular}

$\mathrm{T}_{1}$ refers to the control where only water was applied; $\mathrm{T}_{2}-1$-MCP applied at the first square emission with a second application seven days after the initial application; $\mathrm{T}_{3}-1-\mathrm{MCP}$ applied at the first square emission with two additional applications at seven-day intervals; $\mathrm{T}_{4}$ - 1-MCP applied at the first flower emission with two additional applications at seven-day intervals; $\mathrm{T}_{5}$ - AVG applied at the first square emission with a second application seven days later; and $\mathrm{T}_{6}-\mathrm{AVG}$ applied at the first flower emission with a second application seven days later. Means followed by the same letter are not significantly different at the $\mathrm{p}<0.05$ level by Student's statistical tests (LSD). 
In contrast to the SCY and FY, the \% Fiber and final Stand did not significantly differ, independently of the ethylene inhibitors treatments (Figure 2 A, B, C and D). As shown in this figure, the $\mathrm{T}_{2}$ and $\mathrm{T}_{5}$ treatments resulted in enhanced SCY and FY, independently of the ethylene inhibitors used probably because the first treatment occurred during the first square emission. In this growth season, the AVG sprayed at first square emission with a second application seven days after the initial application $\left(\mathrm{T}_{5}\right)$ generated the highest values for the SCY and FY (Figure 2A and B).
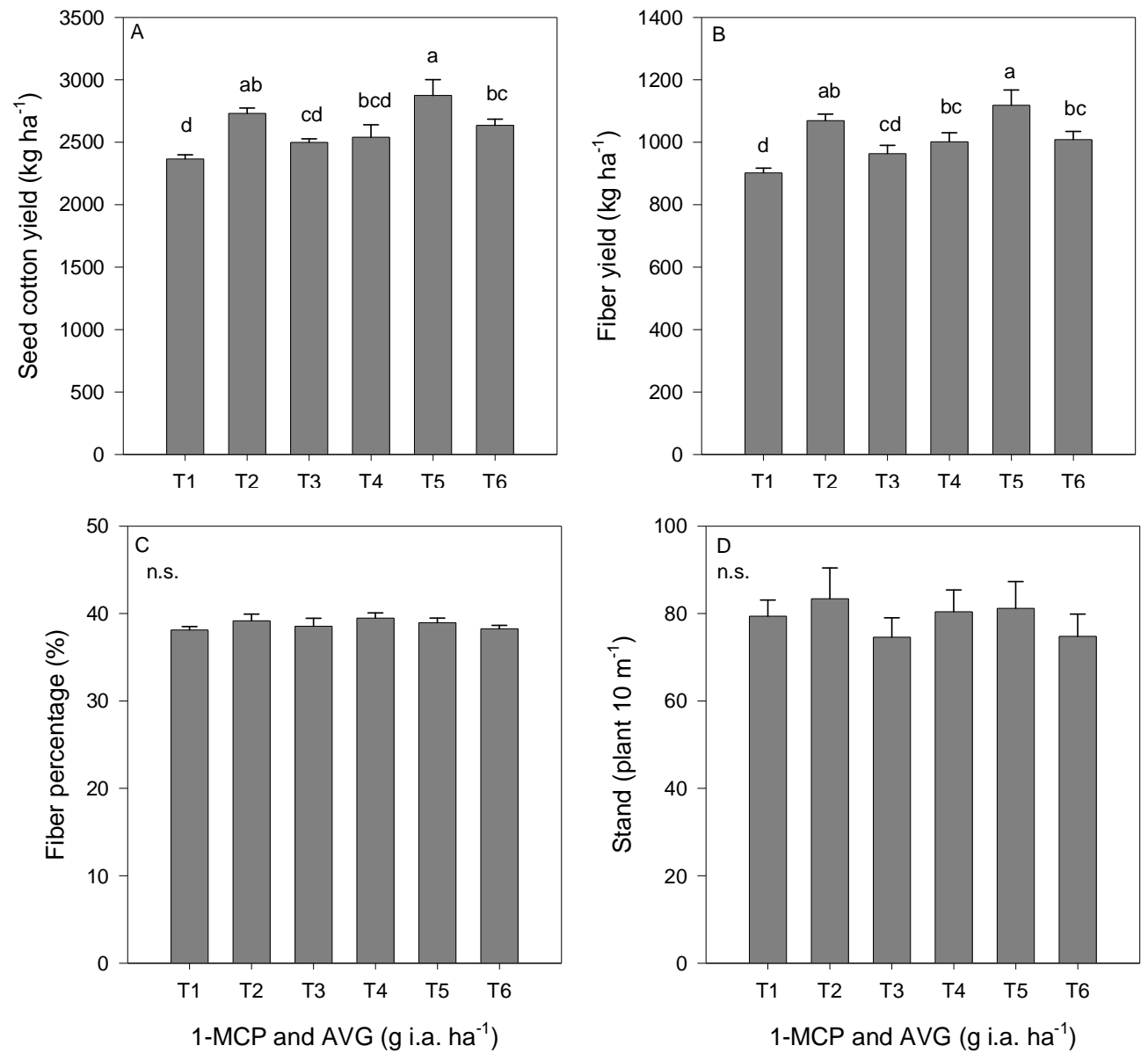

Figure 2 - Cotton yield components from plants subjected two sources of ethylene inhibitors during the reproductive phase in the second growth season. $\mathrm{T}_{1}$ refers to the control where only water was applied; $\mathrm{T}_{2}-1-\mathrm{MCP}$ applied at the first square emission with a second application seven days after the initial application; $\mathrm{T}_{3}-1$-MCP applied at the first square emission with more two applications at seven-day intervals; $\mathrm{T}_{4}-1-\mathrm{MCP}$ applied at the first flower emission with two more applications at seven-day intervals; $\mathrm{T}_{5}-\mathrm{AVG}$ applied at the first square emission with a second application seven days after the initial application; and $\mathrm{T}_{6}-\mathrm{AVG}$ applied at the first flower emission with a second application seven days after the initial application. Means followed by the same letter are not significantly different at the $\mathrm{p}<0,05$ level by Student's statistical test (LSD).

Ciênc. agrotec., Lavras, v. 37, n. 1, p. 9-16, jan./fev., 2013 
early cotton boll development, during which the plants demand for water is significantly increased. The occurrence of a water deficit, particularly during the reproductive phase, can negatively impact the physiology, growth and yield of the cotton crop (SARANGA et al. 2004; ULLAH et al., 2008; BRITO et al., 2011). This report demonstrates that, in general, the ethylene inhibitor applications mitigated the effects of water deficit on the SCY and FY. Although the role of ethylene on cotton plants growing under field conditions is not fully understood, positive effects of 1MCP on the physiology and yield of field-grown cotton were demonstrated (KAWAKAMI; OOSTERHUIS; SNIDER, 2010), in cotton subjected to water deficit when 1-MCP was sprayed during the first flower emission phase. These effects could be explained by the fact that the 1MCP applications inhibited the cotton stress response, as evidenced by the low antioxidant activities and higher quantum yield, and consequently increased the boll weight and seed number per boll. Similarly, AVG treatment was verified to impact the seed cotton yield, and this effect resulted from changes in the boll number which, in turn, may have been caused by differences in the level of fruit abscission due to the changes in ethylene synthesis in cotton plants submitted to water deficit (Personal communication). As shown in our report, 1-MCP and AVG applications resulted in higher SCY and FY when compared to untreated controls.

However, the same effect was importantly demonstrated during the first growth season, when no water deficit occurred. In this case, the ethylene inhibitor applications increased the cotton productivity when compared to the untreated control. In this case, the occurrence of cloudy days during the cotton growth season, especially in December and January (INMET, 2012), which increase ethylene synthesis and can determine the ratio of shed reproductive structures, including squares, flowers and bolls, in the initial development phase may be involved in the results. These results not only emphasize the potential role of ethylene in mediating the response of cotton plants to environmental stressors but also demonstrate the effects of the ethylene inhibitors on the negative impacts of this hormone on cotton yield. Because there is a consensus that the primary driving force for natural shedding is the source/sink imbalance, which determines the relative rates of production and transport of various hormones in the plant which, in turn mediate developmental delays (BAKER; BAKER, 2010), new studies to evaluate physiological and biochemical variables are necessary to elucidate the mechanisms involved in the response of cotton plants sprayed with ethylene inhibitors.

\section{CONCLUSIONS}

In our report, the 1-MCP and $\mathrm{AVG}$ compounds were able to reduce the negative consequences of environmental stressors on SCY and FY, suggesting that cotton ethylene production may play a significant role in yield performance. More research is required to understand the physiological roles of ethylene and ethylene inhibitors. In addition, more detailed investigations are required into the practicality of applying these compounds as a commercial management practice when the risk of imminent environmental stress is known.

\section{REFERENCES}

BAKER, D.N.; BAKER, J.T. Cotton Source/Sink Relationships. In: STEWART, J.M. et al. (Ed.).

Physiology of Cotton. Dordrecht Heidelberg London New York: Springer, 2010, p.80-96.

BRITO, G.G. et al. Physiological traits for drought phenotyping in cotton. Acta Scientiarum-Agronomy, Maringá, v.33, p.117-125, 2011.

FISCHER, E.M.; SCHAR, C. Consistent geographical patterns of changes in high-impact European heatwaves. Nature Geoscience, London, v.3, p.398-403, 2010.

FUJITA, M. et al. Crosstalk between abiotic and biotic stress responses: a current view from the points of convergence in the stress signaling networks. Current Opinion in Plant Biology, Amsterdam, v.9, p.436-442, 2006.

INSTITUTO NACIONALDE METEOROLOGIA-INMET. Dados da Rede do INMET. Dados do período compreendido entre Novembro de 1971 e Dezembro de 2011. Disponível em: http://www.inmet.gov.br/portal/ index.php?r=estacoes/estacoesAutomaticas. Acessado em: 10 de julho de 2012.

\section{INTERGOVERNMENTALPANELONCLIMATE}

CHANGE-IPCC. Observations: surface and atmospheric climate change. In: Solomon, S. et al. (Eds.), Climate Change 2007: The Physical Science Basis. Contribution of Working Group I to the Fourth Assessment Report of the Intergovernmental Panel on Climate Change. Cambridge University Press, Cambridge, UK \& New York, NY, USA. 2007, p.124-182. 
KAWAKAMI, E.M.; OOSTERHUIS, D.M.; SNIDER, J.L. Physiological effects of 1-Methylcyclopropene on wellwatered and water-stressed cotton plants. Journal of plant growth regulation, New York, v.29, p.280-288, 2010.

SARANGA, Y. et al. Genetic dissection of cotton physiological responses to arid conditions and their interrelationships with productivity. Plant, Cell and Environment, Maiden, v.27, p.263-277, 2004.

STEWART, J. M. et al. Physiology of Cotton. London Springer Dordrecht Heidelberg, 2010, 563p.
TAIZ, L.; ZIEGER, E. Plant Physiology. 5th ed. Plumtree Road, Sunderland, MA: Sinauer Associates, Inc., 2010, 782p.

TAKIZAWA, E.K. Manejo da cultura do algodoeiro no cerrado. In: FREIRE, E. C. (Ed.) Algodão no cerrado do Brasil. Goiânia: Associação Brasileira dos Produtores de Algodão - ABRAPA, 2011, p.439-472.

ULLAH, I et al. Genotypic variation for drought tolerance in cotton (Gossypium hirsutum L.): Leaf gas exchange and productivity. Flora, Aschaffenburg, v.203, p.105-115, 2008 